\title{
Implementation of Feedback as an Important Element of Modern Corporate Websites
}

\author{
Yuriy Golchevskiy \\ Institute of Exact Sciences and Information Technologies \\ Pitirim Sorokin Syktyvkar State University, Syktyvkar, Russia
}

yurygol@gmail.com

\author{
Andrei Yermolenko \\ Institute of Exact Sciences and Information Technologies \\ Pitirim Sorokin Syktyvkar State University, Syktyvkar, Russia
}

ea74@list.ru

\begin{abstract}
The Internet has become an independent global electronic environment for economic activity, which for many companies has come to the forefront, not only complementing but also replacing the business methods used for decades. Almost any company, linking its activities to the Internet, develops and maintains its representation in the form of a corporate portal or website. Sites become more functional, more beautiful and informative over time, but many managers forget or do not pay due attention to such an important element of the site as feedback from external and internal contractors. This article presents the effectiveness of using feedback on specific examples in a simple and straightforward way, and gives an overview of the different forms of organisation of such communication, with an indication of possible tools for their implementation.
\end{abstract}

Keywords: feedback, corporate website, communication with customers, organizational culture, sales support.

\section{Introduction}

It is impossible to imagine modern society without the Internet. Moreover, while the Internet was originally a means for promoting goods and offline services, it is now an independent global electronic environment for economic activity, which largely determines activities and strategic ways of business development. The use of Internet technologies leads to increased productivity, increased sales and improved relationships with consumers. One of the most widespread and widely used means of conducting such activities is corporate websites and portals that contain relevant, accessible and reliable information and are a link between the organisation and its counterparties [1], [2]. Modern websites provide direct access to the market, direct communication with target consumers, and not only opportunities to conduct marketing research, but also effective tools to influence consumers, development trends and demand in their market segment, improve their image, etc. 
From a marketing point of view, the objective of the sales website is to transfer a potential customer to a real customer, then, with the help of specialised offers, to make him a regular customer and, as a result, make him a partner [3]. It is important to note that using the corporate website, the company can provide customers with additional services in addition to sales: provide various analytics and detailed information on products and services, independent feedback, and provide pre- and after-sales service. [4]:

A modern understanding of corporate websites requires the following elements

- unified corporate design;

- registration and authorisation module;

- description of activities, company mission, contacts;

- news feed;

- a system of internal and external messages;

- organisation of joint work;

- forums (or other similar means of communication);

- guest books, feedback and voting forms;

- the company's knowledge base.

According to the authors of this research, such elements as news feed, message system, chats and chat rooms, forums, guest books, contacts, voting, feedback forms, tools for forming a permanent audience of visitors (subscribers) to the site, email distribution, activity in the site's accounts on social networks, mobile applications can be combined with one term "feedback". It is not always given sufficient attention when designing, developing and maintaining a website.

The purpose of this article is to provide a comprehensive study of the purpose and ways of implementing feedback from a management point of view, and to highlight the importance of this tool for business.

\section{Research Methods}

This research is based on the analysis of business requirements, current trends in the development and application of web-technologies, on the analysis of publications and scientific discussions on this topic. Observation and comparison methods were used based on data obtained during interviews with business representatives and professional IT communities. In particular, the findings are based on discussion of this problem with specialists from several companies:

- The Centre of Information Technologies is a state autonomous institution working in the field of development, implementation and maintenance of software for state and municipal structures;

- Aqua Delivery Company, working in the field of development and provision of specialized service for automation and development of water delivery business in eight countries, and Dodo, providing food delivery service;

- an organization working in the financial sector in the Komi Republic. 
The authors' experience gained through years of practice in participating in IT projects, for example, has been taken into account:

- for city services (e.g. "Komi Republic in numbers”, “Active Syktyvkar”);

- for museums (the National Museum of the Komi Republic and the Museum of Archaeology and Ethnography at the University of Syktyvkar);

- journal sites "Bulletin of Syktyvkar University. Series 1: Mathematics. Mechanics. Informatics" and "Human. Culture. Education";

- for educational and medical institutions;

- development of terms of reference for web-resources of the Syktyvkar University.

The authors also participated at various times in the support of several web resources, in particular, the official website of the Syktyvkar University and its components. In such projects, there has always been a question of organizing feedback and its maximum convenience for both parties.

The experience of eight graduates of our university of different years was also interesting from the described point of view. They worked in IT-services of various companies and organizations providing IT and financial services, public administration institutions and companies of technological sector, starting from 2012.

This led to the identification of problems in the organization of feedback from a management point of view, both from external contractors and the organization of effective intra-corporate feedback, as well as problems in the technological implementation of feedback.

\section{Results}

\subsection{Feedback From a Management Point of View}

\subsubsection{Feedback From External Contractors}

We will show the importance and necessity of using feedback on websites in various situations. We will begin the description with market research, which makes it possible to adjust the assortment policy and improve the service in accordance with the wishes of [5] clients. For example, market research for educational institutions makes it possible to track and update the requirements of employers and the global market in educational activities and adjust them in time. A study by [6] showed the advantages of a feedback system for graduates compared to manual questionnaires or other methods of improving the curriculum, while [7] shows possible options for organising feedback from university applicants. High-quality feedback support is a modern web design trend [8].

Increased number of channels for communication with customers - all types of advertising, website, mobile application, social networks, chat rooms, messengers, etc. - requires the diversity and improvement of content, focusing on target information consumers and potential customers. 
Online reviews are an important information base for customers to create an opinion on possible purchases. At present, before buying a product, people study the feedback about it on various resources. So why not make it possible to discuss it on your site? Encouraging people to buy is discussed in various articles, in particular an article [9] examining the use of video announcements to create online reviews.

Feedback from the tourism industry, which is one of the most important economic activities, and from some regions is crucial. Here feedback is used to collect and refine information both for tour selection and to support tourists in their journey. A study by [10] shows that tourists give priority to the three main types of feedback - chat rooms, e-mail and telephone. Customer feedback on these tours is also important for potential buyers of tours.

Customer support through the corporate website can be realised through knowledge bases made using wiki [11], [12] technology. Working together on knowledge bases can also be seen as a feedback element, as it allows you to express your vision of different business processes.

Feedback can be seen as an element of support for the organisation's image, as it enables the assessment of the goods and services offered, the actions of the company's employees and the information provided. With the advent of social media, company mistakes are easily brought into the public domain by customers and responding to them becomes not just good practice, but a vital necessity to avoid problems and stimulate a positive attitude towards business or brand. More companies begin to pay attention to their image on the web and monitor what they and their competitors are saying on the network.

There are business projects that simply cannot work without feedback. For example, work [13] describes an application that is integrated with the database on the restaurant's website and provides notifications for orders so that the customer knows the status of the order.

Some business ideas are that the customer can control the entire production or service process. An example is the pizza making process [14].

It is extremely important now to implement the possibility of interacting with customers on social networks. This is due to the fact that social networks have become not only a platform for communication for the next generation, but also a tool for finding content, such as brand information, and making purchases. $37 \%$ of Western users are subscribed to various brands on social networks. Shopping with the help of social networks (Social Commerce) is modifying the usual approach to sales today. In many Asian countries, users already prefer social media shopping, while Western countries prefer traditional online retailers, although the Social Commerce segment is growing [15].

In conclusion of this section, it should be emphasized that monitoring industries, collecting and exchanging views and experiences, improving products, services, scientific calculations and other achievements can also be more useful and costeffective in building effective feedback, as mentioned in the works devoted to GeoFarmer and EOSDIS systems [16], [17]. 


\subsubsection{Intracorporate feedback}

The term "feedback" can be interpreted more broadly - it means not only getting a response from a business customer, but also from an internal corporate customer. It can also be used to solve intra-corporate problems. The management of the company can, through survey forms or other tools for identifying problems, find out the mood of employees, their opinions and suggestions on important production issues, organisational plan problems, and issues of building business processes, thus relieving possible tension in the team and building more efficient production and other business processes.

Based on the results of the feedback, it is possible to revise the company's policy, introduce or change motivational measures, implement the creative ideas of employees, receive information about the career aspirations of employees, their desire to grow and develop and their readiness to improve their skills.

However, feedback from employees will work if they are confident that the information will not be used against them, will reach the recipient, will be heard and used in the company's work.

The use of the social network and the intranet can also be seen as an element of feedback. This issue is discussed in an article [18], which describes a software product that allows you to monitor the flow of data related to employees on a continuous basis and, based on this flow, make a judgment about the sentiments within the team.

\subsection{Review of Ways to Implement Feedback}

We will now move on to a discussion of how to implement feedback. We will preliminarily note the following. Quite often, the head of the company does not quite understand the role of the corporate website, and at the same time, removing his or her responsibility, he or she passes on issues of making strategic, image and other important decisions to middle-level managers. However, the growing influence of the Internet on the success of business has led to the realization that the lack of a corporate approach to the management of the site generates many different problems that cannot be solved at the middle level of management. In addition, the corporate website has begun to play a significant role in achieving the strategic goals of the company. Worldwide models suggest highlighting several areas in the corporate website management system and making decisions in each area separately [19]. The proposed model for building a corporate website management system will help to write guidance documents, define decision-making procedures and draw up regulations for website management [2]. In view of the above, top managers should pay attention to the implementation of feedback, as well as the entire site.

The easiest and most obvious way to create feedback is to place an email address in the "Contacts" section where everyone can express their opinion or ask questions. The main advantage of this method is that it is easy to use for small companies, simple and cheap. Shortcomings include the unwillingness of people to write letters, lack of publicity, difficulty in selecting and indicating the intended recipient. 
Feedback forms on the website effectively protect the corporate letterbox from spam and provide a convenient channel for communication with customers. They are not only an effective protection against spam, but also a powerful marketing tool to make the site as convenient as possible for the visitor and eliminate all possible obstacles to contacting the manager, such as unwillingness or inability to call, open a letterbox, register, etc. The feedback form can be implemented as a separately written module, or as a ready-made plug-in in the case of the Content Management System (CMS - Content Management System), or it can be simply used by thirdparty resources such as Google forms.

It is impossible to imagine a modern corporate website without the "News" section. The purpose of this section is not only to convey information about ongoing business processes and improve the image of the company, but also to solve the issues of site promotion in search engines. However, in our opinion, this opportunity is not fully used, as on most sites this section is closed from commenting. The explanation is simple - if there is a possibility of commenting, there should be a moderator who monitors the order, and therefore his work should be paid, which leads to additional costs. At the same time, comments are a great opportunity to get a user's reaction to the company's activities and to study potential customers in more detail, their preferences, vision of the next steps of their favourite brand, etc. This requires allowing comments only to registered users. It should be noted that all modern CMSs contain comment packages, and there is no need for large additional costs for their installation. Also, to protect against spam and unwanted comments, you can use the Akismet capsule or plugins used in CMS WordPress, or JComments and Cleantalk, Komento, Spam protect in CMS Joomla, or the Cackle commenting, feedback and survey system, which supports 8 popular CMSs and provides APIs for developers (https://cackle.pro/).

Another way of obtaining feedback is through a rating system for evaluation or "likes". Modern Internet users want to evaluate publications, goods and services, preferably using simple and familiar tools. Studies presented in [20] show that a significant proportion of social media users take into account the evaluation of previous publications when publishing another post. The use of simple assessment methods can serve as an incentive for developers and sellers of goods and services, as well as for content authors of corporate websites to take into account the preferences of visitors and buyers. As noted by researchers in [21], the lack of evaluation does not necessarily indicate a negative response from users, as users may have encountered difficulties due to interface shortcomings and were unable to vote. The structure and design of the website therefore needs to be well thought out from the start.

When developing the website, it is important to choose the visitor statistics system wisely, as statistics is also an example of feedback, as it allows us to evaluate some parameters of the website users, such as their age, place of residence, education, income, etc. Popular ready-made solutions for maintaining statistics are LiveInternet metrics (https://www.liveinternet.ru/), Yandex.Metrics (https://metrika. yandex.ru/), Google Analytics (https://marketingplatform.google.com/about/), Alexa Rank (https://www.alexa.com/). By the way, ways of recording the behaviour of 
website visitors are currently being developed. These metrics are also quite effective tools for assessing the convenience of the website for visitors.

A fairly popular way to arrange feedback recently has been online chat or online consultant. However, in this case it is necessary to take care of the services of an individual operator or expert consultant. As a special case, it is possible to implement a callback order. A more advanced option is the creation of a website messaging system, the so-called corporate messenger.

For a long time, such feedback methods as forums have been used. Modern popular IT tools for forum creation include IPB, vBulletin and phpBB forum engines. It may be noted that many CMS have their own embedded forum engines, e.g. bbPress in CMS WordPress. However, at present such forums are not very popular with the next generation, which favours similar tools on social networks. In turn, linking modern corporate websites to social networks is a prerequisite for the convenience of sites. Integration with social networks is one of the criteria for ranking sites in search engines. The presence of conversations and groups in social networks is also a way of organizing feedback.

Along with the trend towards integrating corporate websites with social networks, the creation of mobile applications is becoming popular, allowing users to receive feedback and control user interest in various products and the demand for services. There are two main ways to create such tools; the first is to use a built-in browser engine using JavaScript and HTML. The second way is to create native applications for Android [22] and iOS [23]. There is a need to additionally address compatibility issues for various devices [24]. However, given the fact that in recent times mobile traffic has almost equaled, and in some regions it has become more than the traffic of desktop solutions, and in addition, the time spent on the Internet by users using mobile devices is constantly growing, the development of web applications may represent a good strategic solution for business [25].

"Flutter" (https://flutter.dev/), which allows you to create applications in the language "Dart" (https://dart.dev/), can be offered as one of the fairly new but promising platforms for developing mobile applications. At the same time, to create a managed and supported application, it is necessary to adhere to the "Clean Architecture" architecture with the division of the application into independent layers, which allows creating flexible and supported solutions [26]. There is an adaptation of this approach to the Flutter platform, as described in the series of articles on https://resocoder.com/. In this case, the "Business Logic Components" approach, which is relevant for the "Flutter" platform, can be applied [27] to manage page state. Well-established tools such as React Native, Xamarin and Adobe PhoneGap can also be recommended.

In addition, we can note the mechanisms for creating a permanent audience of visitors (subscribers) to the website, which include the organisation of e-mail and SMS links and subscriptions to RSS feeds, and note that this method of feedback organisation as guest books is currently practically unused. 


\section{Conclusion}

The Internet world is rapidly evolving and, as a result, the way corporate websites are created is also changing. The list of ways to organise feedback is not exhaustive, some feedback options are no longer available and new ways may emerge, for example, through voice and video messaging, or through the creation and use of neural networks.

The following conclusions should be noted.

1. CEOs of companies and organisations should not be afraid of using feedback on the corporate website, as it helps collect unique information about the opinions of target visitors, their problems, frequent questions and difficulties. Using this information, it is possible to qualitatively improve the quality of goods and services, improve the content of the corporate website in accordance with the needs of the target audience and, as a result, improve the image of the company.

2. When creating and, in future, when operating the website, attention must be paid to the issues of competent organisation and functioning of various types of feedback. It should be noted that not only feedback from external contractors is important, but also from company employees.

3. It is necessary to use several feedback channels as they improve the usability of the website, provide visitors with different ways of feedback and increase the overall user activity.

4. The use of social networks as a feedback tool has become very popular.

5. It may be recommended that company management should mandatorily set up and discuss issues related to the organisation of feedback and listen to the advice of web studio specialists when developing and re-engineering corporate websites. Investing in these mechanisms, which are a source of invaluable information, is a good investment in the future of business.

\section{References}

[1] J. W. Palmer, "Web site usability, design, and performance metrics", Information Systems Research, vol. 13, no. 2, pp. 151-167, 2002.

[2] E. S. Sultanova, and P. M. Pashkov, "Ways of a corporate web site management system construction" ["Puti postroyeniya sistemy upravleniya korporativnym web-saytom”], Vestnik NSUEM, no. 1, pp. 312-319, 2014.

[3] I. L. Akulich, Marketing: a textbook [Marketing: uchebnik]. Minsk, Belarus: Vysheyshaya Shkola Publ., 2014.

[4] A. V. Yermolenko, "Corporate site in company management" [“Korporativnyy sayt v upravlenii kompaniyey"], Vestnik of Komi Republican Academy of Public Service and Management. Management Theory and Practice series [Vestnik Komi respublikanskoy akademii gosudarstvennoy sluzhby i upravleniya. Seriya "Teoriya i praktika upravleniya”], no. 12, pp. 113-116, 2014. 
[5] O. M. Kultysheva, and O. I. Rukhlyada, "Modern tendencies in organization of the University web site" ["Sovremennyye tendentsii v organizatsii web-sayta vuza"], International Journal of Humanities and Natural Sciences [Mezhdunarodnyy zhurnal gumanitarnykh $i$ yestestvennykh nauk], 2016, no. 1-3, pp. 192-195.

[6] A. Afolabi, E. Eshofonie, and F. Akinbo, "Development of an Alumni Feedback System for Curriculum Improvement in Building Technology Courses", in: Misra S. et al. (eds) Computational Science and Its Applications - ICCSA 2019. ICCSA 2019. Lecture Notes in Computer Science, 11623, pp. 257-265. DOI: 10.1007/978-3-030-24308-1_21

[7] Yu. V. Golchevskiy, and A. M. Surguladze, "Developing and operating experience in online admission system for prospective university students" ["Opyt razrabotki i ekspluatatsii sistemy online priyema elektronnykh zayavleniy ot abituriyentov"], Open Education [Otkrytoye obrazovaniye], no. 6, pp. 57-63, 2012.

[8] Yu. V. Golchevskiy, "Approaches to the modern corporate web resource design and development" ["Podkhody k proyektirovaniyu i razrabotke sovremennogo korporativnogo web-resursa"], Economics. Information technologies [Ekonomika. Informatika], vol. 47, no. 2, pp. 432-440, 2020. DOI: 10.18413/2687-0932-2020-47-2-432-440

[9] R. Velvizhi, S. Sri Gowtham, and D. Jeya Priya. "Examination of early feedbacks for effective product retailing on E-commerce websites", International Journal of Engineering and Advanced Technology, vol. 8, 6 Special Issue 2, pp. 703-706, 2019. DOI: 10.35940/ijeat.F1259.0886S219

[10] D. Liberato, B. Carvalho, and P. Liberato, "The feedback channels in a DMO: Case study in Porto and north tourism association", Advances in Tourism, Technology and Smart Systems. Smart Innovation, Systems and Technologies, vol. 171, pp. 119-130, 2020. DOI: 10.1007/978-981-152024-2_11

[11] A. V. Yermolenko, "Knowledge base as an organization management tool" ["Baza znaniy kak sredstvo upravleniya organizatsiyey"], In Proc.

Economic development in the context of digital transformation. Syktyvkar, Russia, 2018, pp. 25-29.

[12] Yu. Golchevskiy, and A. Yermolenko, "Knowledge Base as an Integral Attribute of a Modern Company", In Proc. International Conference on Economics, Management and Technologies (ICEMT 2020). Advances in Economics, Business and Management Research, Atlantis Press, vol. 139, pp. 548-552, 2020. DOI: 10.2991/aebmr.k.200509.097

[13] R. Salomo, I. Ranggadara, N. R. Kurnianda, and Suhendra, "Multilevel algorithm feedback queue for restaurant order system", International 
Journal of Recent Technology and Engineering, vol. 8, no. 3, Sept, pp. 5000-5005, 2019. DOI: 10.35940/ijrte.C5649.098319

[14] Andrei Arefiev. "Technology in Dodo Pizza" ["Tekhnologii v Dodo Pitstsa"]. [Online]. Available:

https://www.iguides.ru/main/special/rt/pizza2/ [Accessed: Oct. 8, 2020].

[15] Trends 18. The trends to know for 2018. GlobalWebIndex research. Available at: https://cdn2.hubspot.net/hubfs/304927/resourcespage/Content/Trends-18.pdf [Accessed: Oct. 8, 2020].

[16] A. Eitzinger, J. Cock, K. Atzmanstorfer, C. R. Binder, P. Laderach, O. Bonilla-Findji, M. Bartling, C. Mwongera, L., Zurita, and A. Jarvis, "GeoFarmer: A monitoring and feedback system for agricultural development projects", Computers and Electronics in Agriculture, vol. 158, March, pp. 109-121, 2019. DOI: 10.1016/j.compag.2019.01.049

[17] H. Ramapriyan, and J. Behnke, "Importance and incorporation of user feedback in earth science data stewardship", Data Science Journal, 18 (1), 2019. DOI: $10.5334 / \mathrm{dsj}-2019-024$

[18] C. Karthikeyan, D. Poojitha, and P. Rukmini, "Tracking of employees' feedback of an organization using sentimental analysis", International Journal of Scientific and Technology Research, vol. 9, no. 2, Feb., pp. 5836-5839, 2020.

[19] P. Wale, and D. U. Ross, "IT management: experience of the leading companies", International Journal of Recent Technology and Engineering, vol. 8, no. 3, pp. 5000-5005, 2010/2011.

[20] A. De, A. Singla, U. Upadhyay, and M. Gomez-Rodriguez, "Can a user guess what her followers want?", In Proc. 13th International Conference on Web Search and Data Mining (WSDM 2020), 2020, pp. 142-150.

[21] Y. Saito, S. Yaginuma, Y. Nishino, H. Sakata, and K. Nakata, "Unbiased recommender learning from missing-not-at-random implicit feedback", In Proc. 13th International Conference on Web Search and Data Mining (WSDM 2020), 2020, pp. 501-509.

[22] J. Thornsby, Android UI Design. Birmingham: Packt Publishing. 2016.

[23] G. Bennett, S. Kaczmarek, and B. Lees, Swift 4 for Absolute Beginnerss: Develop Apps for iOS. 4th ed. Edition. Phoenix: Apress, 2017.

[24] V. A. Melnikov, "Development process of game engine core for 2D games and interfaces Sad Lion Engine" ["Protsess razrabotki dvizhka dlya 2D igr i interfeysov Sad Lion Engine"']. Bulletin of Syktyvkar Univ. Series 1:

Mathematics. Mechanics. Informatics [Vestnik Syktyvkarskogo universiteta. Ser. 1: Matematika. Mekhanika. Informatika], vol. 33, no. 4, pp. 21-37, 2019. 
[25] S. Kemp, "Digital trends 2019: Every single stat you need to know about the internet". [Online]. Available:

https://thenextweb.com/contributors/2019/01/30/digital-trends-2019-everysingle-stat-you-need-to-know-about-the-internet/ [Accessed: Oct. 8, 2020].

[26] Robert C. Martin. "The Clean Architecture”. [Online]. Available: https://blog.cleancoder.com/uncle-bob/2012/08/13/the-cleanarchitecture.html [Accessed: Oct. 8, 2020].

[27] Chuks Opia. "How to handle state in Flutter using the BLoC pattern". [Online]. Available:

https:/www.freecodecamp.org/news/howtohandlestateinflutterusingtheblo cpattern8ed2f1e49a13/ [Accessed: Oct. 8, 2020]. 